\title{
Chlorotic Dwarf of Eastern White Pine caused by an Ozone and Sulphur Dioxide Interaction
}

CHLORotic dwarf disease of eastern white pine (Pinus strobus L.) is a physiogenic condition characterized by stunted roots and tops, mottled needles and premature foliar abscission. Recent work has indicated that the disease is caused by gaseous pollutants that injure the necdles of genetically susceptible white pines ${ }^{1}$. Wo have now shown that the action and interaction of ozone and sulphur dioxide cause characteristic symptoms on the foliage of white pine ramets that are susceptible to chlorotic dwarf.

Between June and September 1967, we took continuous measurements of ozone and samples of sulphur dioxide every $2 \mathrm{~h}$ from Monday to Friday. We worked in Ohio white pine plantations where there was a high incidenco of chlorotic dwarf, aiming to assess the possible role of these toxicants in the induction of the disease. A Mast ozone meter, equipped with a chromium trioxide scrubber ${ }^{2}$ to eliminate interference from sulphur dioxide, monitored concentrations of oxidant (ozone). Readings were corrected by a factor of 1.5 to give oxidant valucs in terms of neutral KI. Sulphur dioxide was collected with a sequential sampler, and concentrations were determined by the method of West and Gaeke ${ }^{3}$.

Daily $2 \mathrm{~h}$ peak concentrations of sulphur dioxide varied from 0.0 to 7.8 p.p.h.m. Two hour averages of 5.0 p.p.h.m. of sulphur dioxide were recorded on 25 per cent of days. Maximum hourly averages for oxidant (ozone) registercd greater than 5.5 p.p.h.m. for 60 per cent of days. The greatest hourly average was 21 p.p.h.m., and concentrations larger than 10 p.p.h.m. were cornmon. The greatest combination was 12 p.p.h.m. of oxidant and 7.8 p.p.h.m. of sulphur dioxide. Concentrations of sulphur dioxido and oxidant in the field were both greater than 5 p.p.h.m. on 16 per cent of days. Measurements made throughout the summer of 1968 wore similar.

Table 1. MO'PTLING ON WHITE PINE AFTER EXPOSURE TO 10 P.P.M.M. OE SULPHTR DIOXIDE AND/OR 10 P.P.H.M. OH OZONE

Treatment

Ozone

Sensitive

Sensitive

Sulphur dioxide

Sensitive

Resistant

Ozone/sulphur dioxide Sensitive Resistant

Control

Sensitive

Injury was rated on the percentage area of needles showing the chinorotic mottling condition.

In our experiments with ozone and sulphur dioxide we fumigated some resistant and sensitive clonal material of white pine that had been grafted onto $2 \mathrm{yr}$ rootstocks in 1964. White pine plants were placed in a cold storage room in the autumn of 1967, and groups were removed at intervals after 8 weeks. Dormancy was broken in a growth chamber in a regime of $16 \mathrm{~h}$ day, 2,000 foot candles of light, $26^{\circ} \mathrm{C}$ daytime temperature, $21^{\circ} \mathrm{C}$ night temperature and 60-74 per cent humidity. After the buds had broken and the candles had begun to elongate, but bofore the needles separated within the fascicles, the plants were placed in charcoal-filtered chambers ${ }^{4}$.
Sensitive and resistant white pine ramets were exposed to 10 p.p.h.m. of sulphur dioxide, or to 10 p.p.h.m. of ozone, or to mixtures of the two (each in a concentration of 10 p.p.h.m.). Control plants remained in the charcoal. filter grow th chambers. Other white pines were fumigated for 4-8 h each day, 5 days a wook, for 4-8 weeks between January and April 1968 (Table 1).

Symptoms were not observed on any rosistant ramets or sensitive controls. Chlorotic dwarf symptoms of flecking (mottling of current needles), occasionally accompanicd by a shedding of older needles, were noted on most sensitive pines. There was little or no injury to plants treated with one of the gascs, and moderate injury in those treated with the gascous mixture. The percentago of mottling on current needles and the premature drop of older needles exposed to the mixture far exceeded the damage in those treated with one gas. This strongly suggests that the two pollutants act synergistically on sensitive white pine plants. A similar response has been reported in tobacco ${ }^{5}$.

For a brief time during growth, needles were extremely susceptible to damage by pollution. Chlorotic mottling developed 2-4 weeks after cxposure began (about the time that the nccdles separated in the fascicles). Subsequent exposure intensified the mottling only slightly.

We have found that ozone and sulphur dioxide, acting independently or synergistically, can promote the initial symptoms of current needle mottling and promature defoliation associated with the chlorotic dwarf syndrome. Sulphur dioxide secms to be much more reactive than ozone in producing the symptoms.

With continued breakdown of chlorophyll and loss of leaves, as observed in these long term exposures, growth could be reduced through the inability of the leaves to supply the normal photosynthetic needs of white pine plantations ${ }^{6}$.

Other white pine needle blights that seem to be related to air pollution may be caused by a mixture of two or more pollutants. When recorded levels of single gases are not great cnough to damage white pine, mixtures of gases may injure trees before either pollutant would itself cause any darnage.

Environmental factors also directly influence the sensitivity of white pine to one or more pollutant. Further study of these interactions between the suscept and its environment should help to explain variations in the expression of symptoms.

\section{S. DOCHINGER}

F. W. BENDER

Northeastern Forest Experiment Station,

Forest Service,

US Department of Agriculture,

Forest Insect and Disease Laboratory,

Delaware, Ohio.

F. L. Fox

W. W. Hrek*

National Air Pollution Control Administration,

Consumer Protection Einvironmental

Health Service,

US Department of IIealth,

Fducation and Welfare,

Cincinnati, Ohio.

Received July 7 ; revised September $29,1969$.

* Also at: Crops Research Division, Agricultural Research Sorvice, Us Department of Asriculture, Cincinnati, Ohio.

${ }^{1}$ Dochinger, L. S., Scliskar, C. F., and Bender, T. W., I'hytopathology, 55, $1055(1965)$

${ }^{2}$ Saltzman, B. E., and Warlburg, jun., A. F., Anal. Chem., 37, 779 (1965).

${ }^{3}$ West, P. V., and Gaeke, D. C., Anal. Chem., 28, 1816 (1956).

4 Heck, W. W., Dunning, J. A., and Johnson, H., Nal. A ir I'ollution Control,

Menser, H. A., and Fegrested, H. Li., Science, 153, 424 (1900).

${ }^{6}$ Dochinger, I. S., Forest Serv. Res. Note CS-16 (1063). 